\title{
THE USE OF DEMONSTRATION TECHNIQUE IN IMPROVING LEARNERS' SPEAKING ABILITY
}

\author{
Ade Muhamad Ismail Marzuqi ${ }^{1}$, Debi Firdaus ${ }^{2}$, Acep Haryudin ${ }^{3}$ \\ ${ }^{1}$ IKIP Siliwangi \\ ${ }^{2}$ IKIP Siliwangi \\ ${ }^{3}$ IKIP Siliwangi \\ ${ }^{1}$ hafidz.qur@gmail.com, ${ }^{2}$ debifirdaus27@gmail.com, ${ }^{3}$ haryacep@gmail.com
}

\begin{abstract}
This study aims to develop learners' speaking skill at tenth grade of SMK Budi Bakti Utama through Demonstration Technique in procedure text. This research is a Classroom Action Research based on Kurt Lewin' design. This CAR done in two cycle. Every cycle consist of four phases (planning, acting, observing and reflecting). The data were gathered through qualitative and quantitative, namely interview, observation, pretest, posttest and questionnaire. The researcher found that demonstration Technique in teaching procedural text was succes to increase the learners' speaking ability. It is concluded from the learners score. Where, before implementing CAR the mean score was 53.48 and only 6 learners from 33 learners passed the KKM. Then, after implementing CAR the mean score was better became 75.21 and there are 27 learners passed the KKM.
\end{abstract}

Keywords: Speaking, Demonstration Technique, Procedure Text

\section{INTRODUCTION}

Learning English is very important. It is an International language. It is spoken by millions of people all over the world. Furthermore, in global era English is very important to be mastered because no limitation for the people in every country to make a relationship. It is a competitive era. So, people must be ready to face it.

Learners usually meet some difficulties during learning English. So many aspect raised that problems are happened. Some of them are because the technical and untechnical problems. Such as the technique that teacher used did not interested learners, learners feel unconfidents or affraid because they in their mind English is difficult lesson. So, it is need the appropriate technique in teaching-learning process to overcome all the barrier above.

Based on the reason above, the demonstration technique in teaching procedure text is the appropriate way to increase the speaking ability the tenth grade learners at SMK Budi Bakti Utama as the sample and population of the research. Because it is learners center learning where the learners skill is more discovered.

In learning language, learners need to master four language skills. Those are listening, speaking, reading and writing. Listening and writing are regarded as receptive skills while speaking and writing skills are consider to be productive skills (Hedge, 2015). Trying to talk each other is needed to master the speaking and listening skill. Especially for speaking skill, it use to send what is became our thought. Tarigan stated that: speaking is a skill to pronounce the articullation sound or words to expressing, telling or send a thought, idea and felling. Speaking is a tool to communicate ideas that arrenged and developed apprropriate with the need of audience or listener (Henry Guntur Tarigan, 2015). Brown (2007: 4) in Parmawati (2018) defines speaking as an interactive process of constructing meaning that involves producing, receiving and processing speech of sounds as the main instrument. Based on the previous definitions above, 
it can be conclude that speaking is the process of using the urge of speech to pronounce vocal with the intention of sharing the information, knowledge, idea and opinion to another. Moreover, speaking cannot be separated from listening aspect, because speaking involves speaker and listener.

According to Syaiful Bahri Dzamarah and Aswan Zain, Demonstration Technique is a way in teaching learning with exhibit or show to the learners a process, situation or something that is learned, neither real condition nor imitation by oral explaination (Djamarah \& Zain, 2016). So, demonstration Technique is teaching learning Technique through demonstrate a certain process in directly manner or using teaching realia that relevant with the material is learned.

As others Technique, demonstration Technique also have some advantages and disadvantages (Sanjaya, 2017). Here the advantages and disadvantages based on Sanjaya.

\section{a. Advantages of Demonstration Technique}

Through demonstration Technique verbalism will be avoid, because learners ordered directly pay attention to the learning material that is explained.

1. The learning process is more interesting, because role of the learners not only listen but also watch the process that happened.

2. By doing directly observation, the learners will have a chance to compare the theory with the reality.

\section{b. Disadvantages of Demonstration Technique}

1. Demonstration Technique needs more preparation, because without a good preparation the demonstration process can failed, so can make this Technique uneffective anymore. Moreover, to make a certain demonstration, sometimes the teacher must doing a test first, so it needs a more time.

2. Demonstration process needs some equipments, ingredients and needs a proper place, its means using this Technique need more expensive fee if compare with communicative Technique.

3. Demonstration needs a skill and certain ability, so, teacher and learners is demanded work more professional.beside that, demonstration Technique also need skill and good teacher motivation for successness learners learning process.

\section{Procedure Text}

It is to describe how something is completely done through a sequence of series. According to (Anderson \& Anderson, 2014) procedure text is piece of text that gives us instructions for doing something.

\section{METHOD}

In this study, reseacher use Classroom Action Research (CAR). According Arikunto, CAR is the accuracy of the learning process in action form, that is deliberatly emerged and happened altogether in a class (Arikunto, 2016).

The Classroom Action Research procedure used in this research is Kurt Lewin's design. It consist of two cycles in which each cycle contains four phases; planning, acting, observing and reflecting. As stated by Arikunto that "Classroom Action Research should be implemented two cycles continously" (Arikunto, 2016). This means that a CAR should be conducted at least in two cycles. If the result are less satisfactory, researcher can perform the cycle one again in order to achieve the criteria that have been determined.

Technique of collecting data in this research using quantitative and qualitative data. The qualitative data consist of observation and interview. Meanwhile, the quantitative data uses questionaire, pre test and post test (Arikunto, 2016). 
In analyzing the numerical data, first the researcher tries to get the average of student's speaking skill per action within one cycle. It is used to know how well student's score as a whole on speaking skill. It is uses the formula (Hayati, 2017):

$$
\bar{X}=\sum \frac{x}{n}
$$

$$
\begin{aligned}
& \bar{X}=\text { Mean } \\
& \mathrm{x}=\text { Individual Score } \\
& \mathrm{n}=\text { Numbers of Learners }
\end{aligned}
$$

Then, to get the score from class percantage pass from $65 \mathrm{KKM}$. The researcher uses the formula (Sudijono, 2014):

$$
\begin{aligned}
& \mathbf{P}=\frac{\boldsymbol{F}}{\boldsymbol{N}} \mathbf{X} \mathbf{1 0 0 \%} \\
& \mathbf{P}=\text { The Class Percentage } \\
& \mathbf{F}=\text { Total Percentage Score } \\
& \mathbf{N}=\text { Number of Learners }
\end{aligned}
$$

Next, after find out mean of learners' score per action, the researcher identifies wether or not there might have learners' increasement score on speaking skill from pre test and post test score in cycle 1 and cycle 2 . In analyzing that, the researcher uses the formula (Meltzer, 2012):

$$
P=\frac{y 1-y}{y} \times 100 \%
$$

$\mathbf{P}=$ Percentage of Learners' Increasement

$\mathbf{y}=$ Pre Test Result

$\mathbf{y} \mathbf{1}=$ Post Test 1

$$
P=\frac{y 2-y}{y} \times 100 \%
$$

$$
\begin{aligned}
& \mathbf{P}=\text { Percentage of Learners' Increasement } \\
& \mathbf{y}=\text { Pre Test Result } \\
& \mathbf{y} \mathbf{2}=\text { Post Test } 2
\end{aligned}
$$

The Classroom Action Research is success if the criteria of success is reached. And the criteria of succes of this study is given on the following table (1)

Table 1. The Criteria of Success

\section{Criteria of Success}

Instrument 
Process: $65 \%$ of learners are active in speaking class activity.

Produck: $70 \%$ of learners could achieve the target score of KKM 70 of speaking test.
Observation Checklist

Test

\section{RESULTS AND DISCUSSION}

\section{Results}

Pre observation was conducted to learn the condition of tenth grade learners of SMK Budi Bakti Utama during the process of teaching learning in speaking activity before implementing the action. The writer conducted pre observation on $25^{\text {th }}$ August 2018. Based on the pre observation result showed that the class are passive only one or two learners that concern in speaking, most student did not participate in learning activity such as conversation, discussion, and shy in giving oral presentations. They were not courage to involve in the speaking learning process. They were encountered with the hesitance of practicing the material as well as the drilling conducted by the teacher in the learning process. It can said, the learners have problems with their confidence. Therefore, they need a Technique to increase their speaking skill that can overcome the barrier in teaching learning and make the English speaking lesson become interactive and exciting.

The pre test is conducted on $1^{\text {st }}$ September 2018. The pre test had done before the Classroom Action Research in an interview form. Then, the score were taken in five criteria as stated by heaton, which are the scores of pronunciation, grammar, vocabulary, fluency and comprehension (Heaton, 2018).

From the result of pre test, it showed that mean score of pre test was 53.48. It is indicated that learners speaking ability was very low. Only 6 learners who pass the KKM from 33 learners in a class. Here the writer inputted the result of data including the pretest, posttest 1 and posttest 2 into a table as following (2):

Table 2. The Learners Speaking Score of Pretest, Posttest 1 And Posttest 2

\begin{tabular}{rlccc}
\hline No & Name & Pretest & Posttest1 & Posttest 2 \\
\hline 1 & Student 1 & 78 & 79 & 85 \\
\hline 2 & Student 2 & 50 & 65 & 74 \\
\hline 3 & Student 3 & 40 & 55 & 75 \\
\hline 4 & Student 4 & 50 & 70 & 77 \\
\hline 5 & Student 5 & 45 & 60 & 75 \\
\hline 6 & Student 6 & 75 & 76 & 85 \\
\hline 7 & Student 7 & 45 & 60 & 60 \\
\hline 8 & Student 8 & 55 & 65 & 76 \\
\hline 9 & Student 9 & 65 & 72 & 78 \\
\hline 10 & Student 10 & 50 & 70 & 79 \\
\hline 11 & Student 11 & 53 & 72 & 76 \\
\hline 12 & Student 12 & 50 & 64 & 78 \\
\hline 13 & Student 13 & 77 & 78 & 83 \\
\hline 14 & Student 14 & 56 & 70 & 76 \\
\hline 15 & Student 15 & 52 & 72 & 78 \\
\hline 16 & Student 16 & 51 & 70 & 75 \\
\hline 17 & Student 17 & 47 & 60 & 79
\end{tabular}




\begin{tabular}{|c|c|c|c|}
\hline $18 \quad$ Student 18 & 40 & 55 & 75 \\
\hline 19 Student 19 & 50 & 55 & 73 \\
\hline 20 Student 20 & 45 & 45 & 60 \\
\hline 21 Student 21 & 53 & 65 & 65 \\
\hline 22 Student 22 & 76 & 78 & 85 \\
\hline 23 Student 23 & 47 & 52 & 75 \\
\hline 24 Student 24 & 45 & 50 & 75 \\
\hline 25 Student 25 & 45 & 50 & 75 \\
\hline $26 \quad$ Student 26 & 50 & 70 & 76 \\
\hline $27 \quad$ Student 27 & 77 & 78 & 78 \\
\hline $28 \quad$ Student 28 & 50 & 70 & 75 \\
\hline 29 Student 29 & 45 & 53 & 68 \\
\hline $30 \quad$ Student 30 & 40 & 50 & 69 \\
\hline $31 \quad$ Student 31 & 45 & 50 & 68 \\
\hline 32 Student 32 & 40 & 52 & 67 \\
\hline $33 \quad$ Student 33 & 78 & 78 & 89 \\
\hline Total $\left(\sum X\right)$ & 1765 & 2109 & 2482 \\
\hline $\operatorname{MEAN} \overline{(X)}$ & 53,48 & 63,91 & 75,21 \\
\hline
\end{tabular}

\section{Discussion}

Based on the result above, the data showed that the mean score of pretest was 53.48. It means that the learners speaking score before implementing demonstration Technique is 53.48. And the next step is to know the percentage of learners score who passed the KKM (70). It is calculated by using as follow:

$$
\begin{aligned}
& \mathrm{P}=\frac{F}{N} \times 100 \% \\
& \mathrm{P}=\frac{6}{33} \times 100 \% \\
& \mathrm{P}=18,18 \%
\end{aligned}
$$

From that computation, the learners score percentage in the pretest is $18.18 \%$. It means that there are 6 learners who passed the KKM and there are 27 learners are still bellow the KKM. Next, in the cycle 1 of CAR, the writer calculate the result of posttest 1 to know the learners score increasement from the pretest to posttest 1 result. There are three step to get this increasement. Those are calculating the learners mean score of the class, calculating the learners increasement score into percentage and calculating the class percentage. First, based on the result of posttest 1 , the mean score of the class derived 63.91 in which there were 15 learners who passed the KKM (70). It showed that there are some increasement from the pretest mean score. It can be seen from the pretest mean score (53.48) to the mean score of posttest 1 (63.91). It increase (10.43). The second step is the calculation to get the percentage of learners increasement score from pretest to posttest 1. It is used computation as follow: 


$$
\begin{aligned}
& P=\frac{y 1-y}{y} \times 100 \% \\
& P=\frac{63.91-53.48}{53.48} \times 100 \% \\
& P=19.50 \%
\end{aligned}
$$

The third step is to know the percentage of learners score who passed the KKM (70) in posttest 1. It is calculated by using as follow:

$$
\begin{aligned}
& P=\frac{F}{N} \times 100 \% \\
& P=\frac{15}{33} \times 100 \% \\
& P=45,45 \%
\end{aligned}
$$

From that calculation, the class percentage which passed the KKM is $45.45 \%$. It means that in the cycle 1 of CAR, there are 15 learners who passed the KKM and there are 18 learners whose score are bellow the KKM. The learners increasement which passed the KKM is $19.50 \%$. Eventhough it is still needed more increasement because it could not achieve yet $70 \%$ as the target of success CAR.

Furthermore, in cycle 2 of CAR the writer also calculate the result of posttest 2 to know further the score increasement either from the result of pretest or posttest 1 . There are three steps to know this increasement. Those are to calculate the mean score of the class, to percentage of the learners increasement score, and to calculate the class percentage which pass the KKM (70). Firstly from the calculation, the mean score of posttest 2 is 75.21 . It means, there are some learners increasement scores (11.3) from the mean of posttest 1. The second step is to know the calculation of percentage of learners increasement score. Here, the writer computes by using the formula:

$$
\begin{aligned}
& P=\frac{y 2-y}{y} \times 100 \% \\
& P=\frac{75.21-53.48}{53.48} \times 100 \% \\
& P=40.63 \%
\end{aligned}
$$

Based on that computation, it could be seen that the posttest 2 increase $40.63 \%$ from the pretest or $21.13 \%$ from the posttest 1 . And the last step is the writer tries to get the class percentage whose score pass the KKM. It uses the calculation as the following:

$$
\begin{aligned}
& P=\frac{F}{N} \times 100 \% \\
& P=\frac{27}{33} \times 100 \%
\end{aligned}
$$




\section{$P=\mathbf{8 1 . 8 1 \%}$}

From that calculation, the class percentage is $81.81 \%$. It means that in the cycle 2 there are only 6 learners bellow the KKM and twenty-seven learners are pass the KKM. The class percentage of posttest 2 showed some increasement from the previous test; the increasement is $63.63 \%$ from the pretest (18.18\%) or $36.36 \%$ from the class percentage of posttest 1 (45.45\%).

\section{CONCLUSION}

The conclusion by using demonstration Technique to increase the tenth grade learners' speaking ability in procedural text at SMK Budi Bakti Utama has significant increasement at learners speaking score. In the pretest, the mean score of learners on speaking test before implementing $\mathrm{CAR}$ is 53.48. It is learners speaking score before they used demonstration Technique. Meanwhile, the class percentage which pass the KKM is $18.18 \%$. It means that there are only 6 learners who are pass the KKM (70) and there are 27 learners out of target.

Next, the mean score in the posttest of cycle 1 is 63.91. It means that there are increasement in some learners score from the previous test (pretest), there is 10.43 or $45.45 \%$. Meanwhile, the class percentage which pass the KKM in posttest 1 is $45.45 \%$. It shows there are 15 learners who pass the KKM. However, it is still needed the increasement because it could not achieve the target yet of success CAR. That is why the writer and the teacher continue the to the second cycle.

Furthermore, the mean score of the second cycle is 75.21. It shows the learners increasement score 11.3 from the posttest 1 or $36.36 \%$. Meanwhile, the class percentage which pass KKM is $81.81 \%$. It means there are 27 learners whose score pass the KKM and there are 6 learners are bellow the KKM. This class percentage shows some increasement $63.63 \%$ from the pretest (18.18\%). The posttest of cycle 2 has fulfilled the target of CAR success, that is above $70 \%$ learners could pass the KKM. It can be said that CAR is success and the cycle of CAR is stop.

\section{ACKNOWLEDGMENTS}

Alhamdulillahirabbil 'alamin. Praise to Allah SWT who has anable the researcher to finish this paper. Peace and salutation for Rasulullah SAW. Thanks to parents, family and our lectures during the completing the paper the researcher obtained many helps, motivations and suggestions.

\section{REFERENCES}

Anderson, M., \& Anderson, K. (2014). Text Types In English. 1. Macmillan Education Australia.

Arikunto, S. (2016). Prosedur Penelitian Tindakan Kelas. Bumi Aksara.

Djamarah, S. B., \& Zain, A. (2016). Guru Dan Anak Didik Dalam Interaksi Edukatif Suatu Pendekatan Teoritis Psikologis. Jakarta:Rineka Cipta.

Hayati, N. (2017). Probabilitas Dan Statistika, (July), 1-76.

Heaton, J. B. (John B. (2018). Classroom Testing. Longman.

Hedge, T. (2015). The Practice Of English Language Teaching. Elt Journal.

Henry Guntur Tarigan. (2015). Membaca. In Paket.

Meltzer, D. E. (2012). The Relationship Between Mathematics Preparation And Conceptual Learning Gains In Physics: A Possible "Hidden Variable" In Diagnostic Pretest Scores. American Journal Of Physics.

Parmawati, A. (2018). Using Analytic Teams Technique To Improve Students'speaking Skill. 
Edulitics (Education, Literature, And Linguistics) Journal, 3(2), 21-25.

Sanjaya, W. (2017). Strategi Pembelajaran Berorientasi Standar Proses Pendidikan. System.

Sudijono, A. (2014). Pengantar Statistik Pendidikan. Rajawali Pers. 